\title{
Effects of intensive versus no management strategies during an outbreak of the bark beetle Ips typographus (L.) (Col.: Curculionidae, Scolytinae) in the Tatra Mts. in Poland and Slovakia
}

\author{
Wojciech GRODZKI ${ }^{\mathrm{a} *}$, Rastislav JAKUŠ ${ }^{\mathrm{b}}$, Eva LAJZOVÁc $^{\mathrm{c}}$, Zuzana SiTKOVÁc, Tomasz MACZKA ${ }^{\mathrm{d}}$, \\ Jaroslav SKVARENINA ${ }^{\mathrm{c}}$ \\ ${ }^{a}$ Forest Research Institute, ul. Fredry 39, 30-605 Kraków, Poland \\ b Institute of Forest Ecology, Slovak Academy of Sciences, Štúrova 2, 96053 Zvolen, Slovakia \\ ${ }^{c}$ Forestry Faculty, Technical University in Zvolen, Masaryka 24, 96053 Zvolen, Slovakia \\ d Tatra National Park, ul. Chałubinskiego 42a, 34-500 Zakopane, Poland
}

(Received 29 October 2004; accepted 27 April 2005)

\begin{abstract}
An intensive bark beetle outbreak occurred in 1993-1998 in the Tatra mountains between Slovakia and Poland. In the Slovak part of the outbreak practices consisted of: no action prior to 1994, intensive pest control management (trap trees, insecticides, salvage cutting) from 1995-1996, active differentiated approach (control measures according to the zonation of attacked stands) combined with intensive use of pheromone traps from 1997-1998. In Poland, the outbreak was mostly located in reserve areas where pest management or other activities were prohibited. Despite the use of intensive pest management measures, tree mortality was not significantly decreased in the Slovak region during the peak outbreak years of 1995 and 1996. Classical forest protection led to an increase in attractiveness of forest edges to bark beetles which could disperse to these areas from locations where no control measures were practiced. Unfavourable weather for bark beetles led to a rapid decrease in tree mortality in both parts of the study area.
\end{abstract}

Picea abies / Ips typographus / outbreak / pest management / mountains

Résumé - Effets de différentes (active vs. passive) stratégies de gestion forestière des pullulations d'Ips typographus (L.) (Col.: Curculionidae, Scolytinae) dans les montagnes de Tatra en Pologne et Slovaquie. Une pullulation massive de scolytes s'est déroulée entre 1993 et 1998 dans les montagnes Tatras, situées entre la Pologne et la Slovaquie. Dans la partie Slovaque de la surface attaquée, la pratique forestière a consisté à ne pas intervenir jusqu'en 1994, puis en une protection active via l'utilisation d'arbres-pièges, d'insecticides et de coupes sanitaires entre 1995 et 1996, et en diverses techniques de lutte diversifiées selon la zonation des surfaces attaqués, combinées à l'utilisation de piégeages à phéromones en 1997 et 1998. En Pologne la pullulation était localiseé en grande majorité dans des réserves strictes où aucune mesure de protection n'était autorisée. Malgré l'importance des moyens de lutte mis en œuvre, la mortalité des arbres n'a pas diminué significativement dans la partie Slovaque pendant les années 1995-1996. Les techniques utilisées aboutissaient à l'augmentation de l'attractivité des bordures de la forêt pour les scolytes, et ceux-ci pouvaient s'y développer en provenance de zones forestières ou le même niveau de contrôle n'était pas appliqué. Un climat défavorable au développement des scolytes a largement contribué à la diminution rapide des mortalités d'arbres observées dans les deux parties de la région étudiée.

Picea abies / Ips typographus / pullulation / protection de la forêt / montagnes

\section{INTRODUCTION}

The Tatra Mountains are the highest mountain range in the Carpathian arch. They are located along the border between Slovakia (75\% of mountain land area) and Poland (25\% of area). The entire Tatra Mts. are protected areas and comprise two National Parks: Tatrzański Park Narodowy (TPN) in Poland, created in 1954 covering 21164 ha, and Tatranský Národny Park (TANAP) in Slovakia, created in 1959 extending over 113221 ha. Both national parks were certified as UNESCO MAB Biosphere Reserves in 1993 [18].

The spruce bark beetles, especially Ips typographus (L.) (Col.: Curculionidae, Scolytinae), represent serious problem for management of both national parks. I. typographus attacks mature spruce trees, causing their mortality. The outbreaks of this bark beetle usually occur in man-made spruce monocultures in areas situated at lower elevations. These outbreaks, classified as pulse eruptive, generally extend from 5 to 7 years

* Corresponding author: zxgrodzk@cyf-kr.edu.pl 


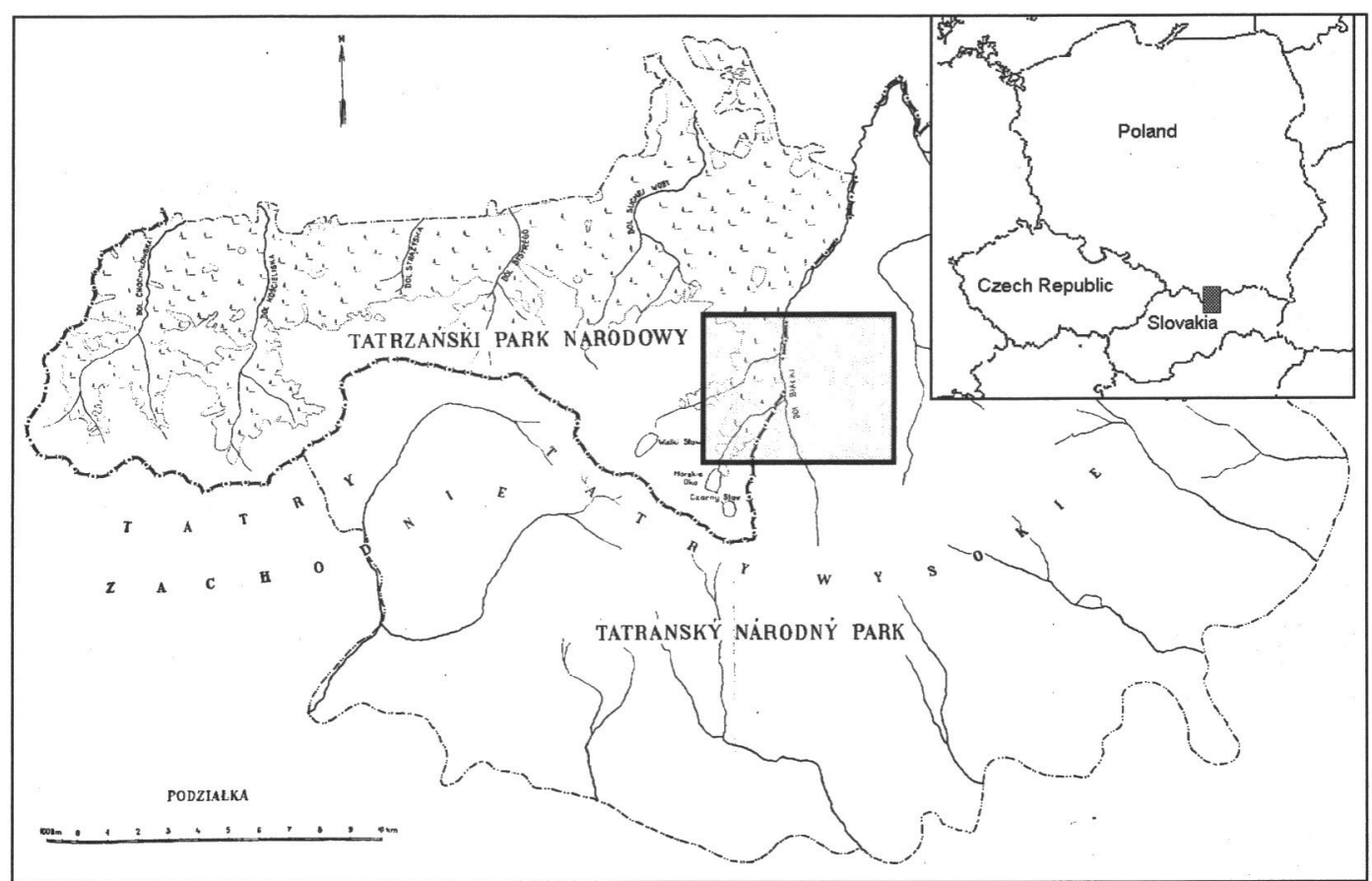

Figure 1. Location of the study area in the Tatra Mts. during which time many trees are killed and decline when the amount of breeding material (weakened trees) decrease or due to the effect of natural enemies/weather conditions action [3, $21,23]$. Recently, several outbreaks occurred also in relatively natural mountainous forests in national parks in Central Europe $[7,12,22,25,30]$.

During the period 1993-1998 an intensive bark beetle outbreak occurred in the Tatra mountains - especially in their eastern portion. Outbreak-related tree mortality affected Norway spruce stands on both sides of the national border. The varying legal regulations governing national park reserves in Slovakia and Poland resulted in the application of different strategies for management of the outbreak in the two countries. The aim of this study was to compare the course of the outbreak on both sides of the national border in relation to both natural conditions and pest management activities.

\section{MATERIALS AND METHODS}

\subsection{Characteristics of selected site and stand conditions}

The present study was carried out in the High Tatra Mts. (Fig. 1), in the area most affected by the bark beetle outbreak. This area belongs to three protection districts: Łysa Polana and Morskie Oko in TPN (Poland) and Javorina in TANAP (Slovakia). The total study area covered 5258 ha including 3441 ha in Slovakia and 1817 ha in Poland. The region was mostly covered by autochthonous mountain Norway spruce Picea abies (L.) Karst. forests, partially (in upper elevations) originated from natural regeneration; at the highest elevations there were also small forest regions dominated by Pinus cembra $\mathrm{L}$. and Pinus mugo L. In the present study, only areas covered by Norway spruce stands over 50-years old were considered. The total area of such stands was 3900 ha (2413 ha in Slovakia and 1488 ha in Poland).The

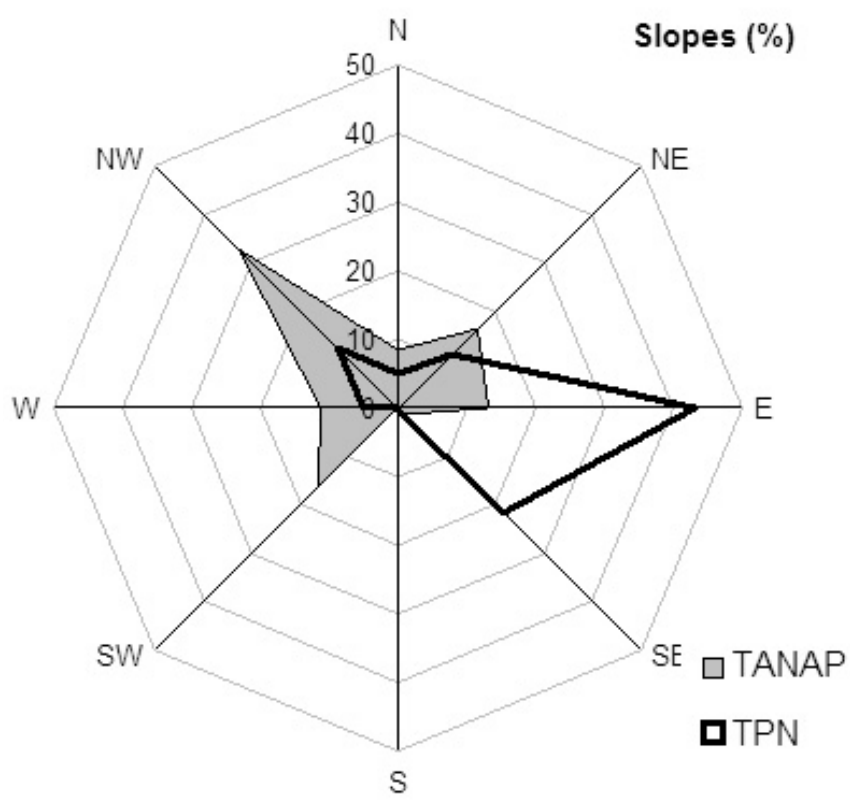

Figure 2. Distribution of the stands (\%) in the mountain slopes in the study area in TANAP (Slovakia) and TPN (Poland).

stands in the study area were characterised by high altitudinal variability: the average compartment's altitude in TANAP and TPN varied from $980-1700$ and $820-1550 \mathrm{~m}$ a.s.l., respectively, but in some cases maximum altitude was slightly higher. The stands were therefore in large range of altitudes, from the lower mountain zone up to the timber line. At the highest elevations there had been fewer man-made changes, and forest ecosystems remained largely in natural condition.

The distribution of stands relative to slope aspects varied among the two sides of the national border (Fig. 2). On the Polish side (TPN) 
eastern and south-eastern slopes are prevalent (44 and 22\% respectively), while on the Slovak side (TANAP) slopes are more evenly distributed among several exposures, with north-western slopes being dominant (32\%). In both countries there were practically no southern slopes (less than 10 ha in each), and the area of flat terrain was negligible ( $1 \%$ or less).

\subsection{Methods}

For the analysis of outbreak dynamics, a database containing detailed data of the stands was assembled. These data were referenced to the forest sub-compartments as basic area units; for each unit, data consisted of the surface in ha, main site and stand characteristics (altitude, exposure, age of trees) and yearly (1991-2000) volume of trees broken/fallen by wind and killed by bark beetles. All data were provided by administrators of both national parks. Due to the nature of the management system applied, records of tree mortality from the Polish part were mostly derived from visual estimations, while data from the Slovak area were based on actual measurements of the volume of felled infested trees and the estimated volume of standing infested trees. Based on the data from forest compartments, mean indices of yearly tree mortality per ha of spruce stands were calculated, then these data were analysed with regard to the temporal dynamics of the outbreak and the distribution of attacked stands in relation to slope position and selected stand characteristics (mainly age). Basic weather measurements (temperature, precipitation) from two stations: Javorina (1014 m a.s.l.) and Dolina Pięciu Stawów Polskich (1668 m a.s.l., data supplied by the Institute of Meteorology and Water Management in Kraków) were also included in the analysis in order to estimate the relation between weather conditions and bark beetle activity.

\section{RESULTS}

\subsection{Management strategies in TANAP and TPN}

\subsubsection{TANAP (Slovakia)}

During the outbreak period some modifications were made in management strategies. The following approaches to pest management were applied: prior to 1994 - no management, 1995-1996 - intensive management (trap trees, insecticides, salvage cutting), 1997 and later - "active differentiated approach" i.e. the differentiation of the control measures (from "no management" to "classic management" + intensive application of pheromone trap barriers) according to the zonation of attacked areas based on their naturalness and ecological stability [27].

Intensive salvage cutting along with the widespread use of trap trees and low intensity of trapping in pheromone traps were conducted from 1995-1996, while after 1996 an active differentiated approach was used $[5,13]$. This approach consisted of the application of different pest management practices in areas with different nature conservation objectives, coupled with intensive use of pheromone trap barriers [11] over the entire area.

\subsubsection{TPN (Poland)}

Management in the Polish portion of the study area remained the same for over 50 years [19]. Fifty-two percent of the study area (the southern, higher localised part) was in a strict reserve where no human activity, including pest management, was permitted. The remaining area is in partial reserve where classic pest management (mainly salvage cutting and pheromone trapping, without the use of insecticides) was practiced.

\subsection{Weather conditions}

The basic climatic characteristics (air temperature and precipitation) from two altitudinally distant (1000 and $1600 \mathrm{~m}$ respectively) weather stations were representative of the conditions in the entire range of the study area. During the decade 1990-1999 periods with distinctly different weather conditions could be distinguished (Fig. 3). The decade began with extremely variable conditions in 1990 (dry) and 1991 (moist), but after 1991 drought conditions (30-45\% below the longterm average) occurred until 1995 at all altitudes. In 1992 and 1994 mean temperatures were $1-3{ }^{\circ} \mathrm{C}$ higher than the long-term average. During the period 1996-1997 precipitation was higher than average (up to $40 \%$ in lower altitudes) and temperature was moderate. Based on the average temperatures from the Javorina station, the years 1992-1995 can be characterised as dry - warm/cold, and the years 1996-1997 as moist - cold.

\subsection{Age structure}

The age structure of stands was different in both parts of the study area (Fig. 4). In the Polish part, where half of the study area remains under strict nature reserve regime, the stands were generally older (up to 200 years vs. 160 years in Slovakia) and the age structure was more differentiated - maximum proportion of one age class was not higher than $20 \%$. In the Slovak portion, a single age class dominated (stands 121-140 years old $-47 \%$ ), and the share of younger classes was not higher than $13 \%$. Even though the total percentage of stands up to 140 years old was equal in both countries, older stands in Poland comprised three additional age classes, but in Slovakia there was only one additional age class. These differences in age structure reflected the more undisturbed nature of TPN stands, which have remained under a very strict nature protection regime for a long period.

\subsection{Characteristics of bark beetle outbreak}

\subsubsection{The course of the bark beetle outbreak}

The course of the bark beetle outbreak was similar in both parts of the study area (Fig. 5) - the mean volume per ha of infested trees, calculated for the entire study areas, was nearly equal in Polish and Slovak areas and highly correlated (Spearman rank correlation $r=0.91, p<0.001)$, especially during the culmination phase (1994-1997). Even if the progradation phase started earlier in Poland, the real beginning of the outbreak (1994-1995) was related to the period of hot and dry weather from 1992-1995 (Fig. 3), which probably negatively affected the Norway spruce vigour and stimulated bark beetle activity and population growth. The collapse of the outbreak was related to a period of cold and moist weather in 1996-1997, unfavourable for bark beetles but positive to tree resistance. The outbreak extended in Polish and Slovak territory on a total surface of 4233 (1487 and 2746 respectively) ha, and resulted 
JAVORINA (1014 m)

Precipitation $[\%]$ and air temperature $\left[{ }^{\circ} \mathrm{C}\right]$ deviations in $[\%]$
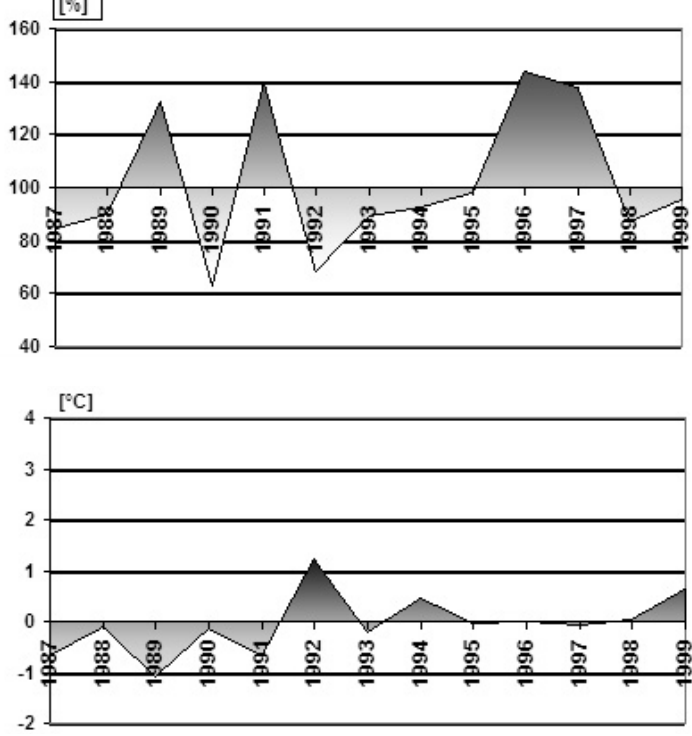

DOLINA PIECIU STAWOW POLSKICH (1668 m)

Precipitation $[\%]$ and air temperature $\left[{ }^{\circ} \mathrm{C}\right]$ deviations in
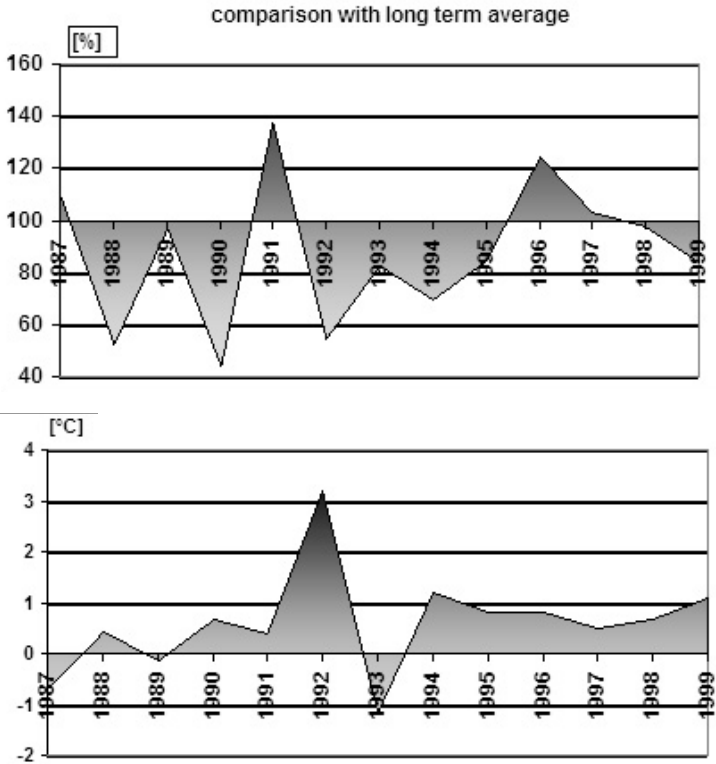

Figure 3. Deviations from long term average monthly precipitation and temperature data during growing seasons $1992-1999$ from 2 stations in the Tatra Mts.

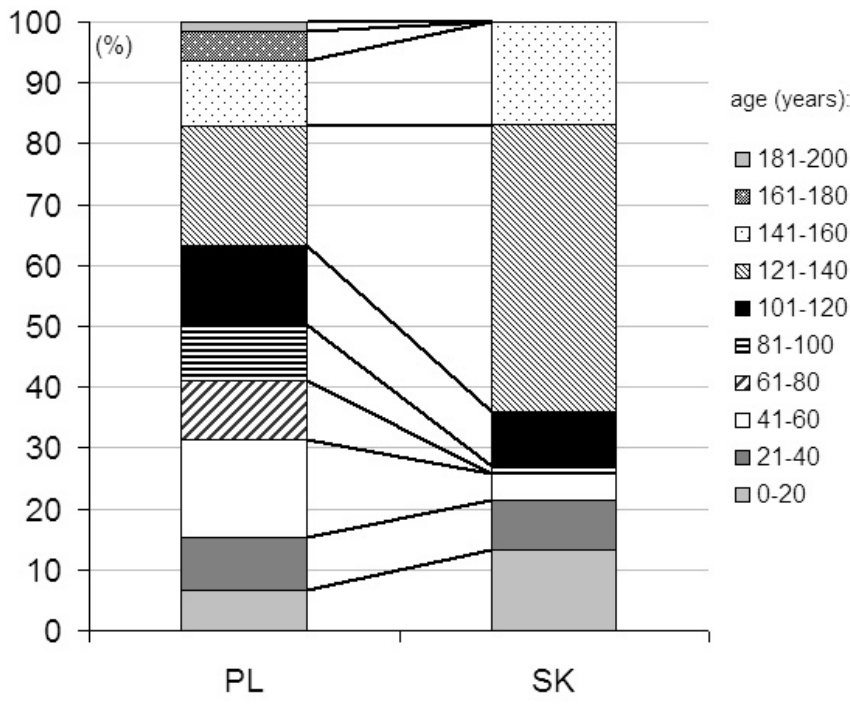

Figure 4. Age structure (\%) of the stands in Polish (PL) and Slovak (SK) part of the study area, based on the percentage of stands in 20years age classes.

in a volume of 118924 (48 534 and 70390 respectively) $\mathrm{m}^{3}$ of killed/felled trees infested by bark beetles. The influence of wind damage cannot be directly estimated - there was no correlation between the volume of windblown trees and the bark beetle attack the forest compartment level, although dispersed damage occurred in both parts of the study area in the period preceding the outbreak: $1200-1300 \mathrm{~m}^{3}$ in 1990 and 1993 in Poland, and 1300-1800 $\mathrm{m}^{3}$ yearly in 1990-1992, and 3100-

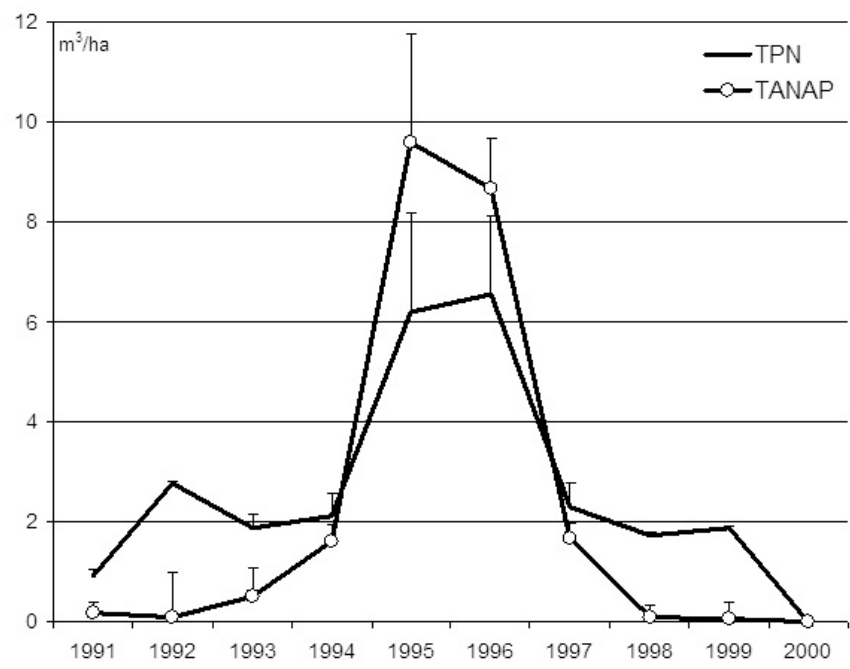

Figure 5. The course of the bark beetle outbreak in TANAP (Slovakia) and TPN (Poland) based on the average volume of trees infested by bark beetles per hectare in $>50$-years old Norway spruce stands.

$7200 \mathrm{~m}^{3}$ in 1993-1994 in Slovakia. However there was not a large amount of concentrated wind damage in the study area during the analysed period.

\subsubsection{Effect of exposure}

The attacked stands in Poland occurred mainly in SE and E slopes, with the highest tree mortality on SE slopes in 1995 


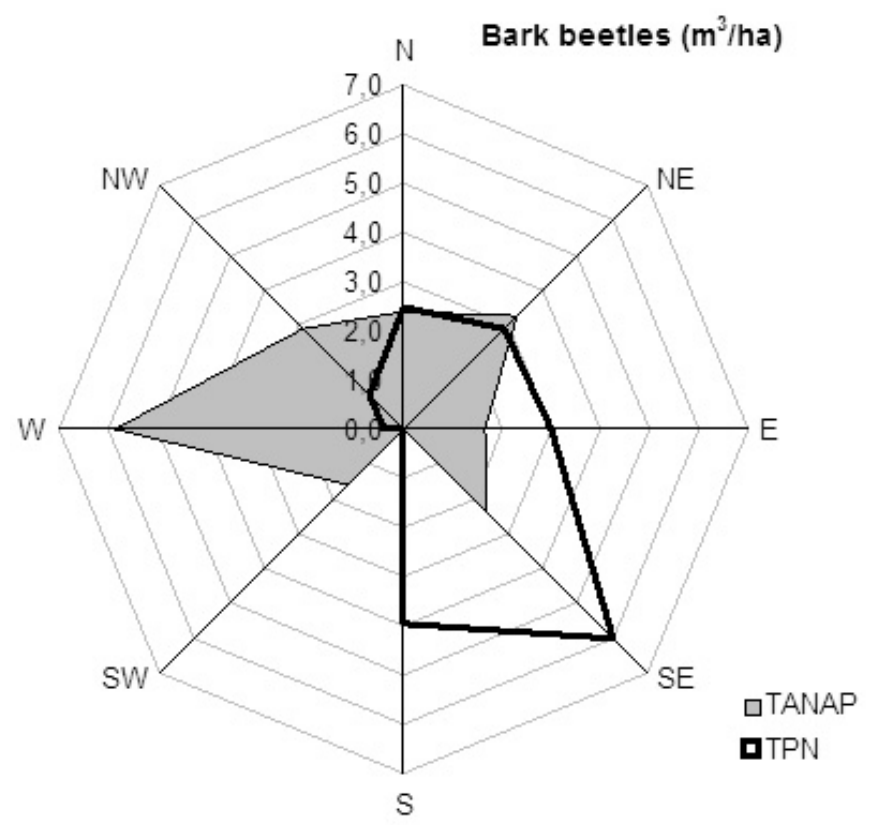

Figure 6. Mean volume of trees infested by bark beetles in TANAP (Slovakia) and TPN (Poland) in regard to the exposure of mountain slopes.

$\left(34.7 \mathrm{~m}^{3} / \mathrm{ha}\right)$. The attacked stands in Slovakia were located on $\mathrm{W}$ and NE exposed slopes, and the highest tree mortality occurred on western slopes in $1995\left(28.7 \mathrm{~m}^{3} / \mathrm{ha}\right)$.

In Poland, most attacks occurred on western slopes (Fig. 6) despite the fact that NW and SW slopes were more common (cf. Fig. 2). Similarly, proportionally more attacks occurred on S and SW slopes in Slovakia, where E sloped were most common. The stands on SE and W exposures generally offer favourable conditions for bark beetle attacks: the most intensive infestations in Krušne hory (Czech Republic) occurred on S and SE slopes [16], and in Western Sudeten (Poland) - on S and W slopes [8].

\subsubsection{Distribution in age classes}

Tree mortality caused by bark beetles differed between the countries in relation to stand age (Fig. 7). On the Polish side, the mean volume of infested trees per ha increased with stand age, according to a linear trend $\left(R^{2}=0.88\right)$. The mortality in the highest age class ( $>180$ years) was $6.7 \mathrm{~m}^{3} / \mathrm{ha}$, but represented a small percentage ( $>2 \%-27$ ha in total). In the Slovak part, the highest indices occurred in 6th age class (101120 years), and decreased in higher age classes, according to a weak polynominal trend $\left(R^{2}=0.63\right)$. The obtained results reflected the age structure of the stands, that was different on both sides of the border. In TPN, total mortality was associated with advanced age and natural tree mortality, which is normal in old Norway spruce stands. In Slovak part, the occurrence of high tree mortality in younger stands (100-120 years) may have been associated with human activity, such as intensive sanitary cuttings in the attacked stands.

\section{DISCUSSION}

\subsection{Outbreak dynamic}

The two examples of bark beetle outbreak dynamics described here are similar to those of other I. typographus outbreaks in Europe. These outbreaks were located either in areas inside and outside of the natural range of spruce forests or at lower portions of the range $[1,3,22,24,26]$. In context to our cases, these outbreaks usually start after extensive wind damage in spruce stands. The synergic effect of wind damage and a series of dry-warm years cause extensive bark beetle population growth and large increases in trees mortality. Krajčovič

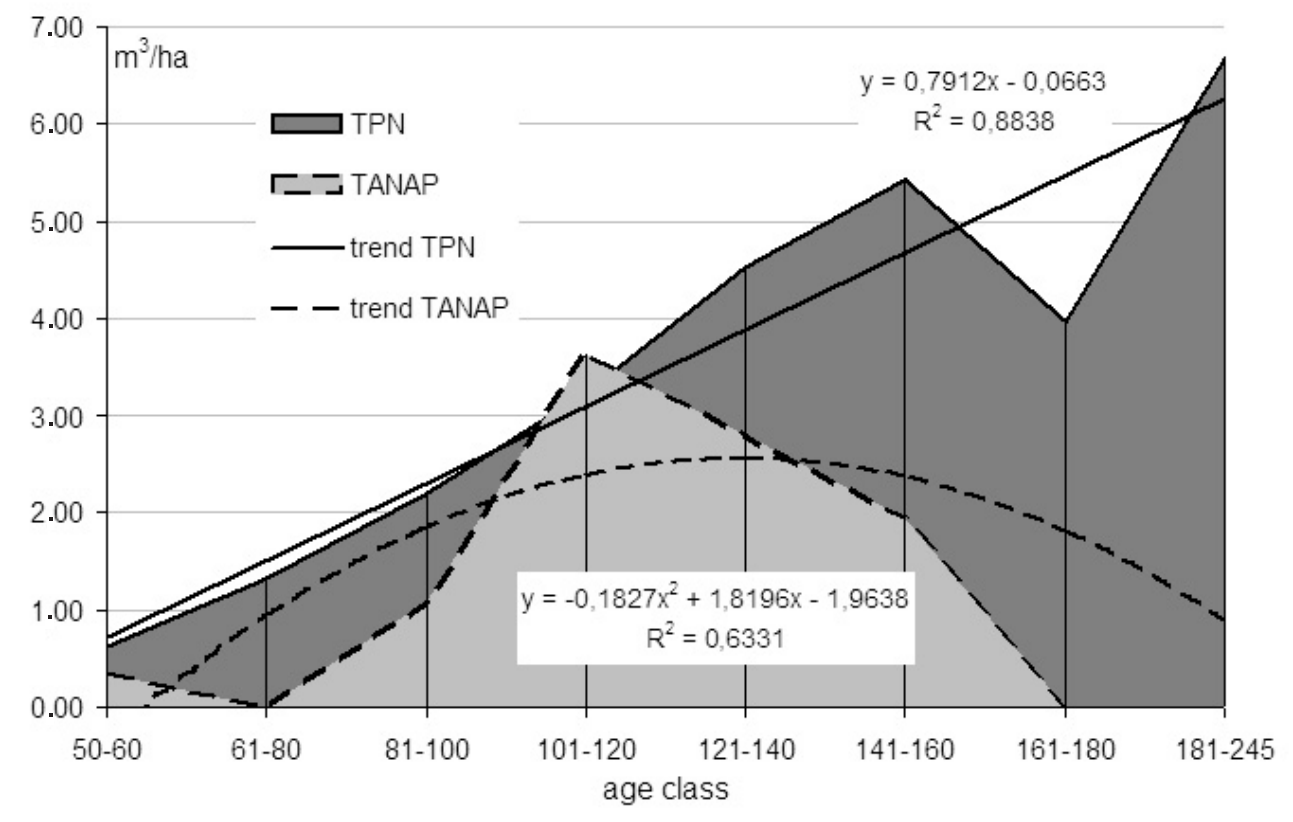

Figure 7. Mean volume of trees infested by bark beetles in TANAP (Slovakia) and TPN (Poland) in regard to the age classes of $>50$ years old Norway spruce stands. 
$[14,15]$ described a previous bark beetle outbreak in the Tatra Mountains in Slovakia. The outbreak occurred after extensive wind damage in valleys to the south and was restricted to lower slopes. Similarly to our cases, outbreaks are often preceded by warm and dry conditions, as described from Norway [29]. The outbreak studied here started in natural spruce stands near the upper timberline in valleys oriented northward, but without any prior extensive wind damage. The proposed action of this type of abiotic factor is the elevation of stand susceptibility to insect attack in forest gaps or edges, and enhancement of conditions for bark beetles. This outbreak may have been caused by the combination of a relatively small and scattered number of wind damage events coupled with a series of hot and dry years. On the Polish part of the Tatra Mountains, prolonged bark beetlecaused tree mortality was observed after catastrophic wind damage $\left(120000 \mathrm{~m}^{3}\right)$ in 1968 [2]. This was the only large bark beetle outbreak recorded there before the outbreak reported in this paper. This indicates that, in these relatively stable Norway spruce stands, bark beetle outbreaks and related tree mortality in the 1990s were caused mainly by weather conditions, combined with the stand characteristics. It also indicates that bark beetles are a natural component in the spruce ecosystem, contributing in the replacement of senescent spruce stands. The decline of the beetle outbreak was probably due to the unfavourable weather conditions in the late 1990s. A similar scenario occurred during the large Scandinavian outbreaks, where spruce mortality caused by I. typographus depended on interactions between the availability of non-resistant breeding substrate (including large areas of continuous spruce forests) and densities of colonizing populations [4, 29].

\subsection{Pest management}

Despite different approaches to pest management, the intensity of bark beetle damage was nearly equal in both parts of the study area (Poland, Slovakia). A similar pattern was also observed in the neighbouring NP Bayerischer Wald region of Germany where no pest management was applied, and in NP Šumava in the Czech Republic where classical pest management (sanitary felling, trap trees and pheromone traps) was used [30]. Thus, control measures do not seem to be able to stop beetle outbreaks, but may mitigate their course, save timber value and simplify management of salvage operations. This similarity of impacts could be partially explained by the migration of beetles from areas with no pest management to areas with intensive pest management. The ability of I. typographus to fly for several kilometers before attacking trees was described by Forsse and Solbreck [6]. The distance between old bark beetle spots and newly emerged attacks can range from a few metres, up to $2 \mathrm{~km}[20,28]$. Genetic investigations on bark beetle sub-populations in the study area indicate high migratory potential of these insects [17]. I. typographus is capable to disperse across high mountain ridges. Thus, the areas with no pest management can act as a source of bark beetles. The basic, most effective method of bark beetle population control is salvage cutting, but this results in the creation of fresh forest edges. Surviving trees on forest edges are stressed by the sudden increase of insolation level, which increases their susceptibility to bark beetle attacks [22]. On the other hand, mechanisms of natural resistance against beetle attacks work in areas with no pest control as well
$[10,22]$. Areas influenced by salvage cutting may be more attractive to bark beetles than areas with no pest control, as a result of primary attraction to logs and stumps and forest edges in recently opened portions of stands [9]. Thus, the two different management approaches may have two different outcomes: clusters of dead trees in no-management zones, and surviving trees between large clear-cuts in pest management zones. The extent of mortality in the clear-cut zone may however be proportional to the respective area in the no-management zone.

The situation in areas under bark beetle control may have been complicated by practices of foresters at the beginning of the outbreak. In 1994-1995, a rapid increase of bark beetle damage on the Slovak part of the study area was recorded. It was caused by mistakes in pest control such as: focusing of salvage cuttings on trees without foliage or with brown foliage from which bark beetles had already emerged instead of the removal of freshly attacked trees with green foliage, extensive use of trap trees, and "preventive" cutting of unattacked green trees on the forest edges. A similar situation was also recorded during the first stages of the outbreak in NP Šumava [22], to a larger extent than in the Tatra mountains. The area of clearcuts after salvage cuttings was considerably larger than the area of dead trees in the no management zone.

Since 1997, an active differentiated approach including the intensive application of pheromone trap barriers was used in Slovakia $[5,11,13]$. Spruce mortality was considerably lower than in the Polish portion of the study area where the outbreak collapsed, presumably due to natural factors. This difference was possibly caused by the effectiveness of protection measures during this period. At least a portion of the dispersing beetles was captured by pheromone trap barriers, and the trees had higher chances to defend themselves against bark beetle attacks [11].

\section{CONCLUSIONS}

(1) Natural factors such as site and stand characteristics and weather conditions are of crucial importance in the development of bark beetle outbreak in old Norway spruce stands. Human activity can contribute to the premature decline of such stands.

(2) Despite the application of intensive pest management measures, tree mortality in the Slovak portion of the study area was not significantly lower than in the un-management area in Poland. Classical sanitary cutting together with intensive use of trap trees led to an increase in attractiveness of forest edges to bark beetles. Beetles colonized these areas from localities with no control measures.

(3) Favourable weather conditions led to a rapid decrease of tree mortality in both parts of the study area. The decrease of tree mortality was more intensive in Slovakia but this may have been due in part to the change in protection strategy (increasing use of pheromone trap barriers instead of intensive sanitary cutting).

(4) In the areas with no control measures the outbreak collapsed at the same time as in the stands under pest control. The main cause of this collapse was probably the effect of cold and rainy weather on trees and bark beetles, as well as the increase 
in the activity of natural enemies (parasitoids, entomopathogens).

(5) The different strategies (no-management and classical pest management) applied in two neighbouring parks resulted in a zone of large clusters of dead trees located between surviving portions of stands in the no-management area, and large clear-cuts between surviving trees in the area with pest management. The area of clear-cuts was nearly equal to that of the outbreak area in no-management zones. The extension of clearcuts can possibly be decreased by the use of pheromone trap barriers.

Acknowledgements: The research was supported by EU-INCO project: "Integrated risk assessment and new pest management technology in ecosystems affected by forest decline and bark beetle outbreaks" (IC15-CT98-151) and by Grant Agency for Science of Slovak Academy of Sciences (2/1162/21). The authors wish to thank the foresters from both national parks for their help in data acquisition and Dr. Andrew Liebhold (USDA Forest Service) for correction of English language.

\section{REFERENCES}

[1] Capecki Z., Badania nad owadami kambio- i ksylofagicznymi rozwijającymi się w górskich lasach świerkowych uszkodzonych przez wiatr i okiść, Prace Inst. Bad. Leś. 563 (1978) 39-117.

[2] Capecki Z., Zasady prognozowania zagrożenia oraz ochrona górskich lasów świerkowych przed owadami na tle szkód wyrządzanych przez wiatr i okiść, Prace Inst. Bad. Leś. 584 (1981) 3-44.

[3] Christiansen E., Bakke A., The spruce bark beetle of Eurasia, in: Berryman A.A. (Ed.), Dynamics of forest insect populations, Plenum Press, New York and London, 1988, pp. 479-501.

[4] Eidmann H.H., Impact of bark beetles on forests and forestry in Sweden, J. Appl. Entom. 114 (1992) 193-200.

[5] Ferenčík J., Jakuš R., Novotný J., Slivinský J., Kalamita lykožrúta smrekového v oblasti Tatranskej Javoriny, Les 54 (1998) 13-16.

[6] Forsse E., Solbreck Ch., Migration in the bark beetle Ips typographus L.: duration, timing, and height of flight, Z. Ang. Ent. 100 (1985) 47-57.

[7] Grodzki W., Bark beetles in the national parks of the Polish mountains, in: Jubilee Conference Forests and Forestry Research for the Third Millenium, Zvolen (Slovakia) 11-14.10.1998, Forest Research Institute Zvolen, 1998, vol. I, pp. 197-202.

[8] Grodzki W., Wpływ osłabienia świerka przez zanieczyszczenia przemysłowe w Sudetach Zachodnich na zagrożenie ze strony szkodników wtórnych, Prace Inst. Bad. Leś. ser. B 25 (1995) 145162.

[9] Grodzki W., Jakuš R., Gazda M., Patterns of bark beetle occurrence in Norway spruce stands of national parks in Tatra Mts. in Poland and Slovakia, Anz. Schädlingskde / J. Pest Sci. 76 (2003) 78-82.

[10] Gutowski J.M., Kubisz D., Entomofauna drzewostanów pohuraganowych w Puszczy Białowieskiej, Prace Inst. Bad. Leś. 788 (1995) 91-129.

[11] Jakuš R., A method for the protection of spruce stands against Ips typographus by the use of barriers of pheromone traps in north-eastern Slovakia, Anz. Schädlingskde. Pflanzenschutz Umweltschutz 71 (1998) 152-158.

[12] Jakuš, R., Grodzki W., Ježik M., Jachym M., Definition of spatial patterns of bark beetle Ips typographus (L.) outbreak spreading in Tatra Mountains (Central Europe), using GIS, in: Mc Manus M., Liebhold A. (Eds.), Ecology, Survey and Management of Forest
Insects, Proceedings of the conference, USDA Forest Service, GTR NE-311, 2003, pp. 25-32.

[13] Koreň M. sen., Fleischer P., Turok J., Bičárová S., Celer S., Koreň M. jun., Kyselová Z., Pavlarčík S., Šoltés, Príćiny podkôrnikovej kalamity v ochrannom obvode Javorina a návrh ozdravných opatrení, Štúdie o Tatranskom národnom parku 3, 36 (1997) 113-187.

[14] Krajčovič A., Prírodné pomery Podbanského (s osobitným zretelom na vetrové a kôrovcové kalamity). I. čast' do roku 1945, Sborník prác o Tatranskom národnom Parku 9 (1966) 159-192.

[15] Krajčovič A., Prírodné pomery Podbanského (s osobitným zretelom na vetrové a kôrovcové kalamity). II. čast's od roku 1945, Sborník prác o Tatranskom národnom Parku 10 (1967) 225-261.

[16] Kula E., Poznamky k disperzi kurovcove hmoty v porostech Lesniho zavodu Horni Blatna, Lesnictvi - Forestry 38 (1992) 221-238.

[17] Lakatos F., Beetle dispersal reflected in genetic structure Migration potential of Ips typographus, in: Integrated risk assessment and new pest management technology in ecosystems affected by forest decline and bark beetle outbreaks, Final report from INCO-Copernicus European research project, 2002 (http:// www.vsv.slu.se/schlyter/tatry_pr/tatrypr.htm).

[18] Mirek Z., Tatry i Tatrzański Park Narodowy informacje ogólne, in: Mirek, Z. (Ed.), Przyroda Tatrzańskiego Parku Narodowego, TPN PAN, Kraków Zakopane, 1996, pp. 17-26.

[19] Myczkowski Z., Od koncepcji sieci rezerwatów ścisłych w Tatrzańskim Parku Narodowym profesora Stefana Myczkowskiego z 1967 r. po plan ochrony TPN w roku 1997, Zesz. Nauk. AR w Krakowie nr 332, Sesja Naukowa z. 56 (1998) 29-34.

[20] Otto L.F., Schreiber J., Spatial patterns of the distribution of trees infected by Ips typographus (L.) (Coleoptera, Scolytidae) in the National Park "Sächsische Schweiz" from 1996 to 2000, J. For. Sci., 47 (Special Issue No. 2) (2001) 139-142.

[21] Sauvard D., General biology of bark beetles, in: Lieutier F., Day K., Battisti A., Grégoire J.-C., Evans H. (Eds.), Bark and Wood Boring Insects in Living Trees in Europe, a Synthesis, Kluwer Academic Publishers, 2004, pp. 63-88.

[22] Schopf R., Köhler U., Untersuchungen zur Populationsdynamik der Fichtenborkenkäfer im Nationalpark Bayerischer Wald, in: Biberlriether H. et al., 25 Jahre auf dem Weg zum Naturwald, Passavia Druckerei GmbH, Passau, 1995, pp. 88-109.

[23] Schwenke W., Grundzuge des Massenwechsels und der Bekämpfung des Grossen Fichtenborkenkäfers, Ips typographus (L.) (Col., Scolytidae), Anz. Schädlingskde. Pflanzenschutz Umweltschutz 69 (1995) 11-15.

[24] Schwerdtfeger F., Pathogenese der Borkekäfer-Epidemie 19461950 in Nordwestdeutschland, Schriftenreihe der Forstlichen Fakultät der Universität Götingen und Mitteilungen der Niedersächsischen Forstlichen Versuchsansstalt 1955, 13/14, 133s.

[25] Skuhravý V., Lýkožrout smrkový a jeho kalamity, Agrospoj, Praha, 2002, $171 \mathrm{p}$.

[26] Stolina M., Problém indiferencie lykožrúta smrekového. Zborník vedeckých prác Lesníckej fakulty VŠLD vo Zvolene 12 (1970) 61-76.

[27] Turčani M., Novotny J., Varinsky J., Hlavné problémy ochrany lesov v Štátnych lesoch TANAP-u z pohl'adu LOS, in: Koreň M. (Ed.), Pät'desiat rokov starostlivosti o lesy TANAP-u, Štátne lesy TANAP-u, 1999, pp. 63-70.

[28] Wichmann L., Ravn, H.P., The spread of Ips typographus (L.) (Coleoptera, Scolytidae) attacks following heavy windthrow in Denmark, analysed using GIS, For. Ecol. Manage. 148 (2001) 31-39.

[29] Worrell R., Damage by the spruce bark beetle in South Norway 1970-1980. A survey, and factors affecting its occurrence, Medd. Nor. Inst. Skogforsk. 38 (1983) 1-34.

[30] Zahradník P., Poznatky z řešení kůrovcové kalamity v národním parku Šumava, in: Varinsky J. (Ed.), Aktuálne problémy v ochrane lesa '98, Lesnícky výskumný ústav Zvolen, 1998, pp. 141-150. 